\title{
Social Media in Teaching-Learning Process: Investigation of the Use of Whatsapp in Teaching and Learning in University of Port Harcourt
}

\author{
Oriji, Abraham (PhD, DLS.) \\ Department of Curriculum Studies \& Educational Technology \\ Faculty of Education, University of Port Harcourt, Nigeria \\ Anikpo, Fanny (PhD) \\ Department of Curriculum Studies \& Educational Technology \\ Faculty of Education, University of Port Harcourt, Nigeria
}

Doi:10.19044/esj.2019.v15n4p15 ～URL:http://dx.doi.org/10.19044/esj.2019.v15n4p15

\begin{abstract}
There is no doubt that digital technologies play major roles in education in modern times. Whatsapp mobile technology has been of immense value in this respect, as it is frequently and globally used in online instruction in universities. As well, it offers students increased choices and opportunities in the context of online instruction. Consequently, the purpose of this research work is to find out exactly to what extent the students and lecturers in the University of Port Harcourt, Faculty of Education are using the Whatsapp instant messaging tool in teaching and learning process in Faculty of Education, University of Port Harcourt, Nigeria. It also tried to find out if the aforesaid have enabling phones that are Internet ready to utilize the Whatsapp software in teaching and learning process. It attempts to discover major challenges, if any that are confronting its effective application in teaching and learning. Descriptive survey approach was adopted. The population for the study comprised of one hundred and twenty-eight (128) lecturers and one thousand six hundred and three (1603) first year undergraduate students of the University of Port Harcourt, Faculty of Education for the year 2017. Three (3) research questions guided the study. The research instrument used was a12 item questionnaire for both lecturers and the students correspondingly. It was validated with a reliability index of 0.70 and considered appropriate for the study. The researchers also employed an in-depth interview method to cover any discrepancy in the structured questionnaire, which was administered to the lecturers and the students respectively. The research questionnaires so retrieved from both respondents were analyzed, using statistical percentile to answer the necessary research questions. The results revealed that regardless of the fact that both the lecturers and the students possess Internet enabled
\end{abstract}


mobile phones, they were not properly utilizing Whatsapp instant messaging for effective academic activities because only 15(11.7\%) of lecturers and 243(22.9\%) of students actually use it for academic purposes. The result further revealed that $100 \%$ of both lecturers and students never received any form of training for the use of Whatsapp mobile technology. Recommendations were also made, which included among others, adequate training on Whatsapp skills and the purchase of Internet enabled phones for effective utilization of Whatsapp instant messaging in teaching and learning process.

Keywords: Social media, WhatsApp application, Teaching and Learning, Mobile technology, and Digital learning.

\section{Introduction and Related Work}

The concern of humans for decades has been on how to interact with friends and families across long distances, and as social animals, they rely profoundly on communication to strengthen their communal relationships. Having observed the limitations of face-to-face interactions, humans have devised means of proffering solutions (Hendricks, 2013).

Consequently, the advances in technology have empowered several methods of doing things quite different from the conventional methods. Social networking/media is a consequence of these developmental strides. Social interactivity has never flourished as perceived in this $21^{\text {st }}$ Century. In recent times, especially in the developed countries, the frequent use of educational mobile technologies in online teaching and learning, particularly in tertiary institutions is gaining much ground worldwide, and it gives students increased choices

(Stead, 2006) and opportunities in the context of online instruction (Amry, 2014; Griesemer, 2012); Makoe, 2010; and Bere, 2013). As well, Seaman and Tinti-Kane (2013) and Person (2010) attest that social media is one of the technologies, which rises within education in or out of classrooms.

Several types of research have revealed that Facebook, YouTube, Twitter and other social platforms have billions of users in which more than $80 \%$ of the active users are mainly youths. In addition to the above, it has also been reported that greater percentage of these active users constitute students, thereby given the conclusion that students are mostly and actively caught up on social networking sites. Their emergence has impacted significantly how students learn and the way instructors teach (Griesemer, 2012).

The under-listed scholars have advanced the advantages of using these technologies in the learning process. For instance, Bouhnik and Deshen (2014); Church and de Oliveira (2013); Nguyen and Fussell (2016) have conducted researches on WhatsApp and noted that the application could be a 
useful tool within the scope of learning anytime and anywhere, and collaborative learning. WhatsApp as one of the instant messaging platforms in education has as well been ascribed to have the potential to increase learning (Smit, 2012).

In addition to learners' being active in their studies, Cifuentes and Lents (2010) and Smit (2012) also established that it facilitates interaction and engagements level between instructors and students. (Laird and Kuh, 2005; Blaschke, Porto and Kurtz, 2010; Jungo, Heiberger \& Loken, 2011). Plana, Escofet, Figueras, Gimeno, Appel, and Hopkins (2013) declared that application of WhatsApp in education process increase students' motivation.

In view of the aforesaid importance placed on mobile technologies, especially WhatsApp, Dunn (2013) has declared that great emphasis must be placed in using technologies within learning process. In the same development, (Laird and Kuh, 2005; Blaschke, Porto and Kurtz, 2010; and Jungo, Heiberger and Loken, 2011) have similarly advocated for educational planners to increase the interaction and engagements level between instructors and students.

Having observed the emergence of these educational mobile technologies in recent times, one will be forced to ask, in Nigerian perspective, how do we familiarize ourselves and apply one of these mobile technologies, especially WhatsApp in digital and/or electronic education?

The social media/networking, especially one of its tools, "WhatsApp" has been embraced by all and sundry, particularly by the youth as advanced earlier. Nigerian youth, no doubt, are actively engaged in online communities. Various institutions in Nigeria today as others worldwide can attest to it that the majority of students and lecturers have mobile phones and are vigorously engaged in online communities. Therefore, it becomes quite necessary to ask some pertinent questions: "Why are the majority of students involved in social media?" "For what purposes are the students' and the teachers' alike using the social media?" And "What are the effects on students' academic performance in schools" Theses scholars, (AbdAlfattah, 2015; Griesemer, 2012; Ibrahim, 2008; Rambe and Bere, 2013; and Attewell, 2005) in their various researches have demonstrated pervasiveness and the positive outcome of application of WhatsApp mobile technology in students' performance in higher institutions of learning. In addition, Nassar (2016) affirmed that the emergence of social networks encourage students to be active in learning and research; at the same time giving them the opportunity to develop collaboration and communicating skills, as well, creating a learning environment to be self-directed learners. The scholar further attests that it has a positive reflection on the students, which support them to share information and collaborate with each other. In another study conducted by Etim, Idongesit and Ema (2016) on WhatsApp 
utilization and students' academic performance, revealed a significant influence of WhatsApp.

Again, the benefits of using social media has also been advanced by (Barhoumi and Rossi, 2013; Blaschke, 2014; Pitler, Hubbell and Kuhn, 2012; and Blaschke, 2014). Listed below are many benefits outlined by these scholars on how social media affects the learning process.

- Increased the communication and collaboration skills between students (when they work as groups)

- Student learned how to make a time management and get result in a shortest way.

- Using social media increased student's motivation and encouraged them to study hard reviewed in early time, and gets higher scores in the exam.

- It enhanced the interaction between students and instructors.

In the same development, Davies (1997) as well, was very optimistic that application of WhatsApp can greatly enhance the quality of learning. While Snelbecker (1999) avowed that technology utilization (WhatsApp) in the tertiary classrooms aids students to perform better in the learning process.

The challenge now is on how to effectively use this social media platform, "WhatsApp" to enhance the education process, instead of using it on infantile things that are meaningless to academic activities. Dunn (2011) was also worried on this issue when the scholar said,"There's no doubt that students are actively engaged in online communities, but what kind of effects are these sites having and how can parents counteract the bad and bolster the positive?" (P.18).

Oriji and Amadi (2016) in their paper titled, "Emerging Technologies in Education: Examining the Role of Online Communication in Nigerian Education System", had also raised this doubt when they stated thus, "Do these numerous social network sites have any educational value?" (p. 48). If yes, is Nigerian populace aware of the value of these Social Networking sites in education setup? Do Nigerian educators and learners utilize this medium to enrich the teaching and learning process? Do Nigerian students really make effective use of this social networking tool (WhatsApp) for education or as leisure activities?

Yes, the social media has come to stay with us, but what positive effects is it having on us, especially on our youth, who are engrossed in it with regards to their academic performances? (Ta'amneh, 2017; Prensky, 2001; Shanmugapriya and Veerakumar, 2016). One would like to ask the following questions, has this social media come to help our education system or to hinder it? How will this help to raise our educational standards? All these questions beg for answers. Researchers have discovered that most colleges and universities surveyed use social media. In one of these researches, it was 
revealed that instructors use it far less for teaching than they do for personal or professional reasons (Tinti-Kane, 2013). In concord, Kurniasih and Riyadhsyah (2018) affirm that many lecturers use WhatsApp group chat to communicate. In this instance, how can the reverse be the case, when lecturers and students will effectively use this platform to enhance performances in the education sector, and when will student make it a hobby to use WhatsApp purely for academic purposes? In view of the above, Luaran, Ghazali and Jain (2014) stressed that both teachers and students are expected to fully utilize technology in classrooms. In the same development, Zhao and Cziko (2001) declared that it is necessary for all teachers to be computer literate by attending computer courses, and also should possess positive attitudes towards ICT learning and upgrade relevant skills. As well, in order to address teachers' inadequacies in ICT, the scholar recommended that senior or elder teachers require more ICT training as they are incompetent in ICT affairs.

\section{Concept of Social Media}

Social media could be conceptualized as the countless collection of Internet-based tools and platforms that enhance the distribution of information, and makes easy the transfer of photos, audio, video, text, and other graphics information among Internet users (Prensky, 2001). Social Media has relevance not only for regular Internet users and business tycoons but also for those in academics. These tools among others include Facebook, YouTube, Twitter, LinkedIn, Blogs, Flickr, Pinterest, and others (Griesemer, 2012; Alfaki and Alharthy, 2014).

It could also be described as the technology and platform that enables the interactive web content formation, collaboration and discussion by contributors. It is a vastly accessible approach of online communication and social interaction, which permits the use of the application in the creation, design and interchange of user-generated context for social networking. These platforms' make it easy to create or form online communities, where people can share personal information as needed with other members.

In summary, social media has been ascribed with the under-listed characteristics: -

- It comprises wide-ranging content formats, such as text, video, photograph, audio, PDF, etc.

- It allows interactions across one or more platforms through social sharing.

- It encompasses different levels of engagement by participants who can create, comment or lurk on social media networks.

- It facilitates improved speed and breadth of information dissemination.

- It creates the possibility for one-to-one, one-to-many and many-tomany communications. 
- It allows communication and interaction to take place in real-time

\section{What is WhatsApp?}

The story of WhatsApp started with Brian Anton and Jan Koom (former Yahoo employees) when the duo launched the application in 2009. "WhatsApp" in English phrase stands for what's up?" meaning "What's new?" WhatsApp, which was later acquired by Google for 1 billion dollars in April 2013, has over 400 million active monthly users (Barhoumi, 2015).

WhatsApp is an instant messaging application for smartphones; or a texting service application that allows users to exchange messages, send videos, written messages, photos, voice messages or voice calls via Internet connections through Blackberry, Windows Phone, iPhones, Android and Nokia phones. WhatsApp requires Internet connectivity for its service(s). Once WhatsApp is downloaded into your phone, you can start sending messages to other users having the same application. This means that WhatsApp messages can only be received by other WhatsApp users, and its service replaces the normal SMS text messages. This has been affirmed by Makoe (2010) and Bere (2013) as the scholars attest that WhatsApp is a superior alternative to SMS messaging.

WhatsApp enables users to interact with friends and relatives across nations free of charge. This is because once users subscribe to an Internet data plan, it uses the same for email and web browsing, thereby attracting no cost to messages sent to others. In the same development, WhatsApp enables users to create groups, and exchange images, videos, and audio or written messages using their Internet connection (Barhoumi, 2015).

\section{Significance of WhatsApp in Teaching and Learning Process}

Technology has simplified most processes of instruction in schools. WhatsApp is one of the learning tools made possible by the technological innovation of the $21^{\text {st }}$ Century. This has been made possible due to some of the popular messaging app's attributes that make it an ideal solution for contemporary teachers and students in the teaching-learning process. However, the main purpose of WhatsApp is communication, and this makes it one of the fastest and most effective channels/means of interaction and learning between teachers and students in the school setting. WhatsApp facilitates communication and an efficient means of dispersing educational resources and information to students. It has been acclaimed that a proper application of WhatsApp in the education arena can bring social media into the classroom. In concord, Barhoumi and Rossi (2013) and Blaschke (2014) affirmed that the use of WhatsApp increased the communication and collaboration skills between students, especially when they work in groups. 
There is a need for modern teachers to learn how to effectively use WhatsApp in order to assimilate themselves into the students' present pattern of learning and make education part of the students' digital activity and lives. Several valuable reasons have been advanced and listed by Berger (2001), Barhoumi (2015), Ketineni (2016), Singhal (2016), and Bhagwat (2016) for the adoption of WhatsApp in the classroom by educators. Major of these are:-

- Groups connected to WhatsApp instant massaging can share learning objects easily through comments, texting and messaging. WhatsApp group chats feature can be used to create learning, virtual classes and study groups for students, especially those students that are sick and not capable of coming to physical class can use this feature to connect with the classrooms.

- Teachers can also use the group chat to make possible discussions with the students outside their classrooms.

- Students can make use of the group chat to solve problems arising from teachers' homework by asking and clarifying issues.

- It can be used to create both text-based messages and audio-based lessons for students, which can be made available directly to them. This can be original lesson prepared by the teacher or recorded lecture already presented to students in the class. The students that missed the lecture can then listen to this lecture repeatedly, thereby given the student the opportunity to learn more.

- It creates equal opportunities for all levels of students to get access to their teachers with minimal cost.

- It could be used directly over the Internet via WhatsApp, Web and WiFi with ease.

- It enables teachers to send graphics (pictures/photos), videos, audio messages and charts to students/learners.

- It facilitates immediate feedback to students' assignment, which may be returned via text and audio files respectively.

- It gives unrestricted messaging to all phones that have Internet connections.

- It is a good avenue for class timing.

- Students use WhatsApp platform to clarify doubts arising from teachers' class assignments

- Teachers and students can be in constant touch outside the classroom, and also within and outside the territorial boundaries.

- Teachers can easily and quickly connect and send academic problems or assignments to students, stay in regular touch with those that missed classes, and equally remind them of future or upcoming assignments. 
- Teachers can easily send academic report cards directly to the parents' phones. Teachers can quickly use WhatsApp to contact parents, especially when they are not in class or not serious with their academic assignments/homework. Parents can also use the medium to regularly appraise the performances of their children and wards.

- The use of these social media tools has no limitation to a wide variety of phones, such as Android, and Windows Phones, Blackberry, Nokia devices, iPhones, etcetera.

- WhatsApp creates a very good platform for students to borrow or exchange class notes from friends.

- WhatsApp facilitates real-time communication with students, teachers and parents.

- WhatsApp group chats feature can be used to create learning and study groups

- WhatsApp instant messaging facilitates online collaboration and cooperation between online students connected from school or home in a blended mobile lecture.

- Information and knowledge are easily constructed and shared through WhatsApp instant messaging.

- WhatsApp provides a better realization of "anywhere, anytime"

- Provides freedom of organization in and out of the classroom

- WhatsApp enables collaboration among students separated geographically

- WhatsApp provides remote sensing and integration of information

- WhatsApp provides a shift from "anywhere, anytime" to "everywhere, every time"

- Mobile learning is a paradigm shift and it changes existing situations in teaching/learning (Smith, 2015).

However, the findings by Attewell (2005), Cavus and Ibrahim's (2008) in their separate empirical studies on the application of mobile and wireless technologies revealed that using the mobile learning tool system was an effective educational tool that contributed to the success of students. Again, the research findings on the research conducted by Attewell (2005) on the effectiveness of mobile technologies on learning revealed that the learners achieved a great improvement in reading comprehension, and learners' motivation also increased towards learning. Rambe and Chipunza (2013) applauded the usefulness of WhatsApp in academics, especially as it helps in fostering knowledge sharing, enhancing peer support on educational affairs and nurturing knowledge communities. 


\section{Challenges of Social Media in Teaching and Learning}

Yes, social media has been credited with numerous advantages for educational purpose. But the demerits inherent in this platform cannot be overlooked. Lots of barriers have been attributed to the use of social media in teaching and learning process. WhatsApp has been said to be addictive, and most students may hardly study effectively when it is installed in their phones. In view of much space usually occupied by pictures/photos, audio messages and videos, it is usually very difficult to backup messages as it takes up much time to undergo this process. Furthermore, it is as well very difficult to stop unsolicited numerous message notifications from entering one's device. In addition, in a situation where a user changes from old device to a new one using the same number, it will be difficult to retrieve the existing chat stored in the old device to the new device. WhatsApp uses a lot of data to operate, especially when downloading images, videos and audio messages. The issue of honesty or integrity has been one of the prevalent obstacles to social media use in teaching and learning. Although the problem of cheating has been a prevalent issue in our traditional institutions, technological innovations have aggravated it in recent times. Student submission integrity is constantly in question. The use of newer technologies has made it impossible to know if actually, the student that claimed to be behind the computer is actually the real student. In fact, some skeptics, without data to support their claims hastily conclude that virtual academic dishonesty is endemic and far worse in online courses than in traditional classrooms (Ubell, 2017).

\section{Theoretical Foundation of the Study}

The paper is based on social constructivist learning theory. The theory seeks to improve collective interactions between students. As Vygotsky (1978) put it, "Social constructivist learning theory seeks to improve social interactions between students and to construct and share knowledge" The theory posits that there is free access to learning resources anywhere, anytime, and in various formats, which enhances deep students' learning capabilities, and as well allows students to construct their own knowledge. The theory emphasized that learning does not reside on one particular person or place, but a connection of experiences, which is made possible via the Internet that provide mobile learning resources in both synchronous or asynchronous modes (Zengin, Arikan and Dogan, 2011). Vygotsky (1978) further observed that construction of knowledge is based on social interactions between online students, and that learning can also be influenced by multiple variables, including the cognitive and psychological state of the learner, teacher professionalism and nature and complexity of the pedagogical approach. 


\section{The purpose of the study}

1. To find out if lecturers and students possess Internet-enabled mobile phones for WhatsApp application in teaching and learning

2. To find out the extent to which lecturers and students utilize WhatsApp account in teaching and learning in the Faculty of Education

3. To find out the challenges faced by lecturers and students on the utilization of WhatsApp in the Faculty of Education

\section{Research Questions}

1. To what extent do lecturers and students possess Internet-enabled mobile phones for WhatsApp application in teaching and learning?

2. To what extent do lecturers and students utilize WhatsApp account in teaching and learning in the Faculty of Education?

3. What are the challenges faced by lecturers and students for utilization of WhatsApp in the Faculty of Education?

\section{Significance of the Study}

The study will enable the Faculty to identify the potential role of new technological advances could play in the education sector. It will enable the Faculty and the University at large to utilize WhatsApp application in teaching and learning process. It will enable the Faculty and the University as a whole to be acquainted with the extent of utilization of WhatsApp application by lecturers and students in teaching and learning process. It will further examine the challenges faced by both lecturers and students on the use of WhatsApp in the education setting. The study will also be an eye-opener for school authorities/administrators, policy makers and implementers on the need to integrate new technologies in the school curriculum as observed in UK by (Wheeler, 2010). It will also be a platform for policymakers, and school authorities to train and retrain faculty members on the use of social networking tools to enhance teaching and learning in schools, as shown by Barhoumi (2015) in his research findings which shows that "WhatsApp" plays essential role in higher education.

It will finally arouse the interest of both lecturers and students on technological adoption and implementation in the education sector. In view of the above interest, Cavus and Ibrahim's (2008) have already indicated that students enjoyed using their mobile phones to learn new words. Also for academic purposes, Chan (2005), Gillingham and Topper (1999) opined that WhatsApp mobile technology provides students with opportunities to interact together and to construct and share knowledge. At the same time, the scholar considered it to be an effective tool for learning and teaching through social interactions. 


\section{Methodology}

This empirical research examined the extent to which students and lecturers in the University of Port Harcourt, Faculty of Education are using the WhatsApp Social Networking tool in teaching and learning process. The researchers adopted a descriptive survey research design for the study to collect and analyze data based on the variables. This is appropriate for this study because the study involved the collection of quantitative and qualitative data from a varied number of respondents by interviewing or administering a questionnaire to a sample of individuals (Tarus, Gichoya, and Muumbo, 2015). The major purpose of descriptive research is for a description of the state of affairs as it exists (Kombo and Tromp, 2006). In the same way, Leedy and Ormrod (2001) pointed out that, "In a descriptive study, the researcher can use the results obtained from the sample to make generalizations about the entire population only if the sample is truly representative of the population. Descriptive survey research and quantitative design was appropriate because it was the easiest and appropriate to obtain and analyze information from the lecturers and the first year students with regards to the application of social media in the teaching-learning process.

The study focused on the Faculty of Education, University of Port Harcourt, Nigeria. The population comprised one hundred and twenty-eight (128) lecturers and one thousand and sixty-three (1063) first-year undergraduate students of the University of Port Harcourt, Faculty of Education for the year 2017. The instrument used for data collection was a-12 item questionnaires for both lecturers and students respectively, titled: "Social media in teaching and learning process: an examination of the use of WhatsApp application in the faculty of education, University of Port Harcourt, Nigeria" constructed by the researchers. The questionnaires were facevalidated by three experts. Two of the experts were drawn from the field of Educational Psychology, Guidance and Counseling, and Measurement and Evaluation of the University of Port Harcourt. While the third expert was drawn from Department of Curriculum and Instructional Technology, Faculty of Education, Ignatius Ajuru University of Education, Rumuolumeni, Port Harcourt, Nigeria. The observations of the three experts formed the basis for the modification of the items of the questionnaires. The research questionnaire was administered to 157 lecturers in their offices, and also to 1178 students in the classrooms respectively. At the end of the exercise, only 128 lecturers and 1063 students responded and returned their questionnaires in that order. Hence, 128 lecturers and 1063 students respectively were used for the study. The researchers also employed interview method to cover some discrepancies in the structured questionnaire. The information gotten was summarized and reported along the results. The data obtained were gathered 
and analyzed, and statistical percentile was used to answer the research questions raised for the study.

\section{Results.}

Research Question 1: To what extent do lecturers and students possess Internet-enabled mobile phones for WhatsApp application in teaching and learning?

Table 1.1: Lecturers' Questionnaire

\begin{tabular}{|l|l|c|c|c|c|c|}
\hline SN & $\begin{array}{l}\text { Items examining the extent to which lecturers } \\
\text { possess Internet-enabled mobile phones for } \\
\text { WhatsApp application in teaching and learning }\end{array}$ & Yes & $\%$ & No & $\%$ & Total/\% \\
\hline 1) & Do you have a mobile phone? & 128 & 100 & 0 & & $128(100 \%)$ \\
\hline 2$)$ & Is your mobile phone connected to the Internet? & 117 & 91.4 & 11 & 8.6 & $128(100 \%)$ \\
\hline
\end{tabular}

Table 1.2: Students' Questionnaire

\begin{tabular}{|l|c|c|c|c|c|}
\hline $\begin{array}{l}\text { Items examining the extent to which students } \\
\text { possess Internet-enabled mobile phones for } \\
\text { WhatsApp application in teaching and learning }\end{array}$ & Yes & $\%$ & No & $\%$ & Total/\% \\
\hline 1). Do you have a mobile phone? & 1057 & 99.4 & 6 & $\begin{array}{c}0 . \\
6\end{array}$ & $1063(100 \%)$ \\
\hline 2). Is your Mobile phone connected to the Internet? & 1021 & 96 & 42 & 4 & $1063(100 \%)$ \\
\hline
\end{tabular}

Table 1.1 and 1.2 above show the extent to which lecturers and students possess Internet-enabled mobile phones for WhatsApp application in teaching and learning respectively. From the results obtained from the respondents (lecturers) in items, 1 and 2 show that $128(100 \%)$ of the lecturers in the faculty have mobile phones, and 117 (91.4\%) of their mobile phones have access to the network. While only 11(8.6) of the lecturers do not have Internet-enabled mobile phones. Secondly, table 1.2 which examined the extent to which students possess Internet-enabled mobile phones for the application of WhatsApp in teaching and learning revealed that 1057(99.4\%) have mobile phones, but only 6(0.6\%) do not have.

\section{Research Question 2: To what extent do lecturers and students utilize WhatsApp account in teaching and learning in the Faculty of Education?}

Table 2.1: Lecturers' Questionnaire

\begin{tabular}{|c|l|c|c|c|c|c|}
\hline & $\begin{array}{l}\text { Items examining the extent to which } \\
\text { lecturers utilize WhatsApp account in } \\
\text { teaching in the Faculty of Education }\end{array}$ & $\%$ & No & $\%$ & Total/\% \\
\hline 1 & $\begin{array}{l}\text { Do you have WhatsApp on your mobile } \\
\text { phone? }\end{array}$ & 111 & 86.7 & 17 & 13.3 & $128(100 \%)$ \\
\hline 2 & $\begin{array}{l}\text { Can you send and receive electronic } \\
\text { messages via your WhatsApp? }\end{array}$ & 105 & 82 & 23 & 18 & $128(100 \%)$ \\
\hline
\end{tabular}




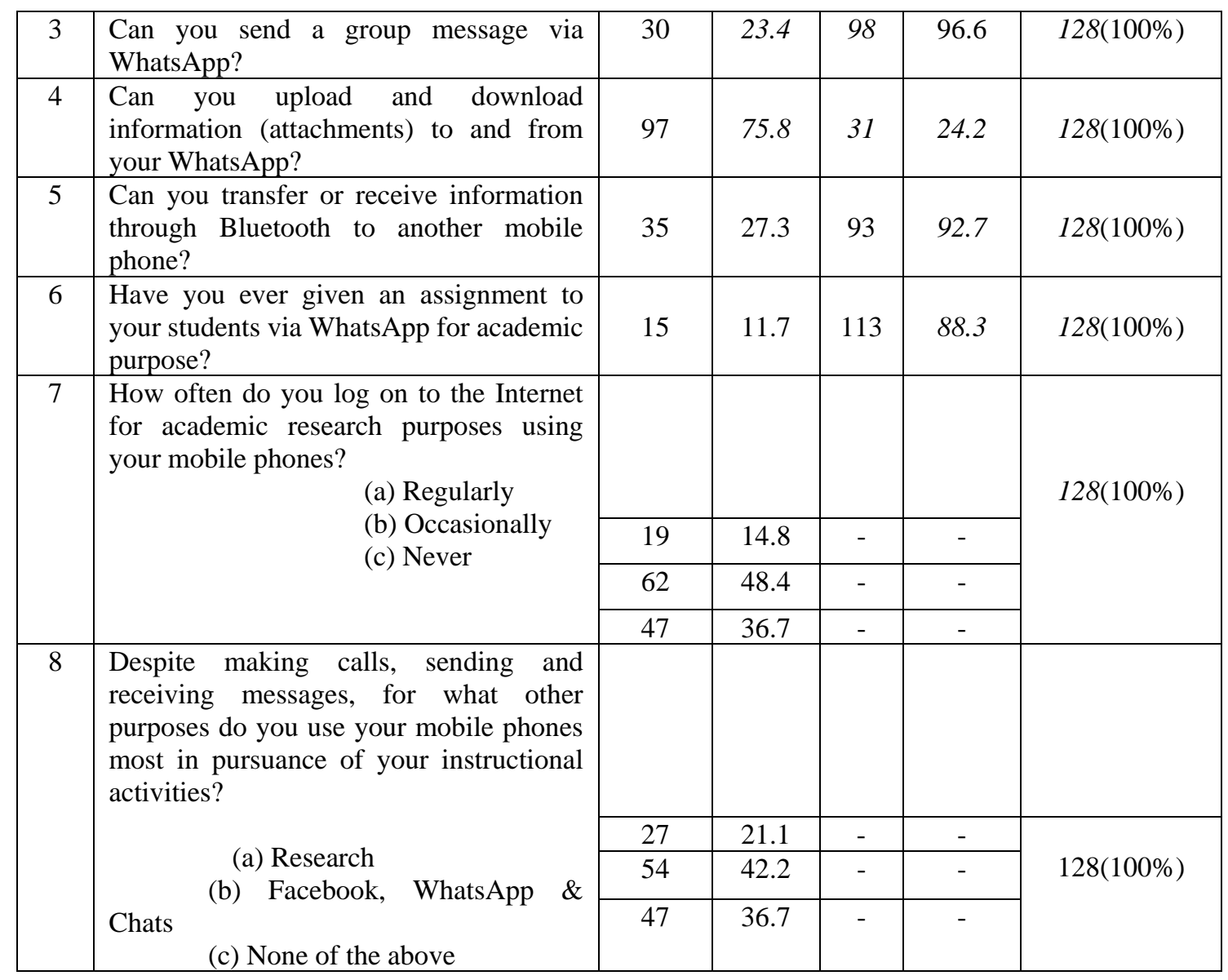

Research Question 2 (RQ2) investigated the extent lecturers and students possess and utilize WhatsApp account in teaching and learning in the Faculty of Education. Table 2.1 revealed that 111(86.7\%) of lecturers have WhatsApp account, while only 17(13.3\%) of them do not have. Again, on the utilization of the WhatsApp instant messaging for teaching and learning in the faculty, which was examined in items 2-4, 6-8 of table 2.1 as displayed above, revealed that only $15(11.7 \%)$ of lecturers, as displayed on item 6 above have ever given assignments to students via WhatsApp, while 113(88.3\%) have never attempted using it for the same purpose. On the matter of sending group message through WhatsApp, only 30(23.45) of lecturers could do it, while 98(96.6) could not. Also, item 8 on the same table 2.1 shows that only $27(21.1 \%)$ of lecturers could $\log$ on to the Internet for regular academic research activities, while 54(42.2\%) effectively use their mobile phones for chatting on Facebook. In the same development, 47(36.7\%) do not even log on to the Internet neither for research purpose nor for chatting on Facebook. For uploading and downloading information (attachments) to and from 
WhatsApp, the results show that 78(60.9\%) have the skills, while $50(39.1 \%)$ do not have the required skills as displayed in table 2.1.

Table 2.2: Students' Questionnaire

\begin{tabular}{|c|c|c|c|c|c|c|}
\hline $\begin{array}{l}\mathrm{S} \\
\mathrm{N}\end{array}$ & $\begin{array}{l}\text { Items examining the extent to which students' } \\
\text { possess and utilize WhatsApp account in } \\
\text { learning in the Faculty of Education }\end{array}$ & Yes & $\%$ & No & $\%$ & Total $/ \%$ \\
\hline & ITEMS ON USE OF MOBILE PHONES & & & & & \\
\hline 1. & Do you have WhatsApp on your mobile phone? & 1006 & 94.6 & 57 & 5.4 & $1063(100 \%)$ \\
\hline 2. & $\begin{array}{l}\text { Can you send and receive electronic messages } \\
\text { from WhatsApp? }\end{array}$ & 1001 & 94.2 & 62 & 5.8 & $1063(100 \%)$ \\
\hline 3. & Can you send a group message via WhatsApp? & 927 & 87.2 & 136 & 12.8 & $1063(100 \%)$ \\
\hline 4. & $\begin{array}{l}\text { Can you upload and download information } \\
\text { (attachments) to and from your WhatsApp? }\end{array}$ & 909 & 85.5 & 154 & 14.5 & $1063(100 \%)$ \\
\hline 5. & $\begin{array}{l}\text { Can you transfer or receive information } \\
\text { through Bluetooth to another mobile phone? }\end{array}$ & 1003 & 94.4 & 60 & 5.6 & $1063(100 \%)$ \\
\hline 6. & $\begin{array}{l}\text { Have you ever been given assignment by your } \\
\text { lecturers via WhatsApp for academic purpose? }\end{array}$ & 243 & 22.9 & 820 & 77.1 & $1063(100 \%)$ \\
\hline \multirow[t]{4}{*}{7.} & \multirow[t]{4}{*}{$\begin{array}{l}\text { Despite making calls, sending and receiving } \\
\text { messages, for what other purposes do you use } \\
\text { your mobile phones most in pursuance of your } \\
\text { academic activities? }\end{array}$} & & & & & \\
\hline & & 55 & 5.2 & - & - & \multirow{3}{*}{$1063(100 \%)$} \\
\hline & & 950 & 89.4 & - & - & \\
\hline & & 58 & 5.5 & - & - & \\
\hline \multirow[t]{4}{*}{8.} & \multirow[t]{4}{*}{$\begin{array}{l}\text { How often do you log on to the Internet for } \\
\text { academic research purposes using your mobile } \\
\text { phones? }\end{array}$} & & & & & \\
\hline & & 45 & 4.2 & - & - & \multirow{3}{*}{$1063(100 \%)$} \\
\hline & & 967 & 91 & - & - & \\
\hline & & 51 & 4.8 & - & - & \\
\hline
\end{tabular}

Table 2.2 examined the extent to which students possess and utilize WhatsApp account in learning in the Faculty of Education. From the result displayed on item 1.1 on the table shows that the majority of the students' numbering 1057 (99.4\%) have mobile phones, and 1021 or $96 \%$ of them have networks. On the utilization of WhatsApp instant messaging for academic work, 1006 or $94.6 \%$ of the students have WhatsApp installed in their mobile phones. On the proper utilization of WhatsApp application for academic activities, item 8 on table 2.2 shows that 243 or $22.9 \%$ of the entire 1063 students utilize it, while 820 or $77.1 \%$ are not properly engaged. Item 10 on the same table shows that only 42(4.2) respondents regularly log on to the Internet for academic research purposes, 967(91\%) occasionally log on, and $51(4.8 \%)$ do not $\log$ on at all. In the same development, item 9 on the table shows that 950(89.4\%) students' use their mobile phones most on Facebook, 
WhatsApp and Chats; 55(5.2) for research and 58(5.5) never involved on anyone.

\section{Question 3: What are the challenges faced by lecturers and students for utilization of WhatsApp in the Faculty of Education?}

Table 3.1: Lecturers' Questionnaire

\begin{tabular}{|c|l|c|c|c|c|c|}
\hline & $\begin{array}{l}\text { Items examining the challenges faced by } \\
\text { lecturers utilization of WhatsApp in the }\end{array}$ & & $\%$ & No & $\%$ & Total/\% \\
\hline Faculty of Education & $\begin{array}{l}\text { Have you ever received training on the use of } \\
\text { WhatsApp in the education process? }\end{array}$ & - & - & 128 & 100 & \\
\hline 2 & $\begin{array}{l}\text { Which of these challenges limit your effective } \\
\text { utilization of WhatsApp in the Faculty of }\end{array}$ & & & & & \\
$\begin{array}{l}\text { Education? } \\
\text { (i) High cost of data }\end{array}$ & $\begin{array}{l}\text { (ii) Lack of Internet-ready mobile phone } \\
\text { (iii) Lack of money to buy a mobile phone }\end{array}$ & 11 & 8.6 & 117 & 91.4 & $128(100 \%)$ \\
\hline $\begin{array}{l}\text { (iv) Lack of electricity to charge mobile } \\
\text { phones for browsing }\end{array}$ & - & - & 128 & 100 & $128(100 \%)$ \\
\hline (v) Lack of training and skills & 95 & 94.2 & 33 & 25.8 & $128(100 \%)$ \\
\hline
\end{tabular}

Table 3.1 shows that $128(100 \%)$ of the lectures received no training on the use of WhatsApp in academic activities.

\section{Table 3.2: Students' Questionnaire}

\begin{tabular}{|l|l|c|c|c|c|c|}
\hline & $\begin{array}{l}\text { Items examining the challenges faced by } \\
\text { students utilization of WhatsApp in the Faculty } \\
\text { of Education }\end{array}$ & Yes & $\%$ & No & $\%$ & Total/\% \\
\hline 1 & $\begin{array}{l}\text { Have you ever received training on the use of } \\
\text { WhatsApp for education purpose? }\end{array}$ & 0 & 0 & 1063 & 100 & $1063(100 \%)$ \\
\hline 2 & $\begin{array}{l}\text { Which of these challenges limit your effective } \\
\text { utilization of WhatsApp in the Faculty of } \\
\text { Education? }\end{array}$ & & & & & \\
(i) High cost of data & & 1011 & 95.1 & 52 & 4.9 & $1063(100 \%)$ \\
\hline $\begin{array}{l}\text { (ii) Lack of Internet-ready mobile phone } \\
\text { (iii) Lack of money to buy a mobile phone } \\
\text { (iv) Lack of electricity to charge mobile } \\
\text { phones for browsing }\end{array}$ & 42 & 4 & 1021 & 96 & $1063(100 \%)$ \\
\cline { 2 - 7 } (v) Lack of training and skills & 6 & 0.6 & 1057 & 99.4 & $1063(100 \%)$ \\
\cline { 2 - 7 } & & 964 & 90.7 & 99 & 9.3 & $1063(100 \%)$ \\
\hline
\end{tabular}

Item 1 on table 3.2 shows that none of the students received training on the use of WhatsApp for academic purposes. Item 2 shows that 1011 or $95.1 \%$ of students had a high cost of data challenges. Additionally, 1046 or $98.41 \%$ of respondents affirmed that lack of competence limits the utilization of WhatsApp application. At the same time, 964 or $90.7 \%$ complained that lack of power limits their use of mobile phones for browsing. 


\section{Discussion of Findings}

Based on the above results on table 1.1 , it has been proven that lecturers possess mobile phones that are capable of undertaking any teaching and learning process via the WhatsApp instant messaging, but a closer look at the results on tables 3.1 and 3.2 revealed that both the lecturers and the students are not adequately using WhatsApp platform for most academic purposes because they received no training on its use. In support of the above, Gachago, Strydom, Hanekom, and Simons (2015) wondered and stated thus: "while literature continues to promote mobile learning and, in particular, the use of mobile phones for teaching and learning in blended and open distance learning (ODL) to bridge the digital divide, many lecturers still struggle to understand and engage with it to support their teaching practices." (P.1). Tables 3.1 indicate that 128 or $100 \%$ of the lecturers never received any training on the use of WhatsApp for academic purposes. While table 3.2 also revealed that 1063 or $100 \%$ of the students never received training on the use of WhatsApp mobile application for academic purposes. It was on this ground that the Malaysian state of Perak carried out various teacher trainings programmes on ICT use in education (Yin, 2016). In the same development Zhao and Cziko (2001) recommended that is necessary for all teachers to be computer literate by attending computer courses.

The second findings on table 2.1 also revealed that WhatsApp application is grossly underutilized because only 15 or $11.7 \%$ of lecturers actively involved students academically in the Faculty. Despite the fact that $111(86 \%)$ of the lecturers possess Internet-enabled mobile phones as shown in table 2.1, the result revealed that the platform is used on infantile activities, especially by the undergraduates as displayed in item 1 of table 2.2 (1006 or $94.6 \%$ ), thereby using the precious time meant for serious academic work for unnecessary chatting, exchange of pictures and videos. This agrees with Barnes, et al, (2013) that the use of WhatsApp is personalized than academic activities.

Furthermore, item 2 on table 3.2 shows that electricity is one of the problems facing the students for effective utilization of WhatsApp as 964 or $90.7 \%$ of respondents agreed to it. If the phone batteries are not charged, it will be extremely difficult for lecturers and students to perform

Further findings as well revealed that high cost of data constrains the effective use of mobile phones for browsing for both lecturers and students as depicted in table 3.1 and 3.2 respectively.

\section{Implications of the Research Findings}

The study revealed that the Faculty and the University as a whole need to train their lecturers' for effective use of mobile phones for digital education. This is in agreement with Aishareef (2018) on his research concerning the 
importance of using mobile learning in supporting teaching and learning of English in secondary stage. The scholar recommended among others, active use of mobile devices, and the establishment of training courses for supervisors and teachers... Other inhibitions, such as electricity and high data cost should be looked into by the Faculty and the University at large. This is also in agreement with Aljehani (2013) who expressed concerns on users who need to download large files that take a long time, as mobile providers' will bill enormous data charges to users. Consequently, the provision of the above facilities will enhance the effective use of mobile technologies in teaching and learning process.

\section{Future/Possibilities for Digital Education}

With the digital platform or mobile technologies around us today; further improvements to digital learning technologies, and with the devices becoming cheaper and more interconnected, we strongly envisage a better opportunity as Stead (2006) put it, "the future is more mobile, more connected and more personalized. New generations of learners will expect this as the norm. They will be connected with many different devices, and demand equality, inclusion and always-on access wherever they are." Once more, new technologies are emerging that allow devices to come together and communicate among themselves and as well enabling anything to be connected to the Internet from anywhere and anytime; still more thrilling are those advances that we have yet to imagine that will revolutionize teaching and learning in the years to come (Sharpe, 2006).

\section{Recommendations}

For appropriate digitization of education in this part of the world, the researchers' recommend among others, that lecturers' and students' should purchase Internet-enabled phones for effective utilization of WhatsApp instant messaging in teaching and learning process. The Faculty should provide training opportunities for both lecturers and students to enhance their skills/competencies on the efficient use of mobile phones, and particularly the WhatsApp instant messaging. The lecturers should as a matter of priority engage the students academically by constantly giving them assignments through WhatsApp instant messaging. This recommendation has been supported by researchers. For instance, Dougherty (2012) declared that "assignments create teaching and learning opportunities to think and learn about ideas, topics, events, and questions-about specific content in the curriculum", and "a well-crafted assignment ensures that instruction will provide students with a goal and the power to get there, enabling them to engage in rigorous and interesting academic contexts as they acquire the content and skills necessary to participate in academic coursework." Most 
importantly, the scholar stressed further that, "a well-crafted assignment takes into account what students can handle, while simultaneously stretching them. It clearly states the immediate goal and articulates the challenge in terms students can understand." In addition, the author stressed that, "it tells students what to do and how well to do it. Assignments are also aligned to long-term goals, whether those goals are building toward proficiency on assessments or college and workplace readiness."

Consequently, in order to disengage them from negative aspects of social media which influence their studies, the lecturers should also provide sufficient time for face-to-face academic and/or social interactions in order to minimize students' involvement in infantile (chatting) activities on WhatsApp. These methods will to a large extent reduce or remove most of the times used on infantile and negative aspects of social media that influence students' academic work. Further, the university should as a matter of priority assist the lecturers through loans to provide high-quality mobile phones that are Internet-enabled for effective browsing. The university and the faculty, in particular, should source for companies, private organizations, wealthy individuals' within and outside the university community to help provide Internet-enabled phones for both lecturers and students in the Faculty. The Faculty should as well send lecturers and students for training to enhance their skills/competencies on the efficient use of mobile phones, and particularly the WhatsApp instant messaging. Research findings by Rambe and Bere (2013) revealed that the use of mobile instant messaging leverage learner participation and transform pedagogy at a South African University of Technology. Researches by Dror, 2008; Attewell, 2005; and Hanekom, Simons and Walters; 2015) as well, revealed that learners achieved great improvement in reading comprehension, promote teaching and learning in blended and open distance learning, and learners' motivation also increased towards learning.

The university should as a matter of policy adopt the use of WhatsApp instant messaging by making it compulsory for teaching and learning. Conclusively, the faculty and the university at large should organize workshops, seminars and orientations on the use of WhatsApp in teaching and learning process (Gachago, Strydom, Hanekom, and Simons, 2015).

\section{Conclusion}

The world has gone digital in almost all aspects. With modern technological advances, most countries of the world have started embarking on the digitized education system, and Nigeria as a country, especially at this time of democratization of education and subsequent admission quandary in recent times, cannot afford to remain behind and watch the world as their education system go digital. As a result, WhatsApp as one of the technological 
breakthroughs must be fully embraced for efficient electronic teaching and learning in Nigerian schools. The Faculty and the University at large must provide the needful; create substantial awareness and adequate training to enhance electronic education delivery in this part of the world in order to race with time. In spite of the fact that the study revealed that majority of the lecturers and students possess Internet-enabled mobile phones, they are not tailored purely for academic purposes. WhatsApp mobile application technology has been found to be one of the beneficial ways for learning. Hence, there is a need to utilize this platform for academic use (Makoe, 2010) and Bere, 2013).

\section{References:}

1. Aishareef, F. (2018).The importance of using mobile learning in supporting teaching and learning of English in secondary stage. Journal of Education and Practice. 9(15), P.71-88.

2. Aliehani, W. (2013). Disadvantages of mobile learning. Retrieved 28 January, 2019 from https://www.slideshare.net/wafaaaljehani/disadvantages-of-mobile-learning

3. Amry, A. B. (2014). The impact of WhatsApp mobile social learning on the achievement and attitudes of female students compared with face to face learning in the classroom. European Scientific Journal, $10(22), 116-136$.

4. Attewell, J. (2005). Mobile technologies and learning: A technology update and m-learning project summary. London: Learning Skills Development Agency.

5. Barhoumi, C. \& Rossi, P. G. (2013). The effectiveness of the instruction oriented hypertext systems compared to direct instruction in e-learning environment. Contemporary Educational Technology, 4(4), 281-308.

6. Barhoumi, C. (2015). The effectiveness of WhatsApp mobile learning activities guided by activity theory on students' knowledge management. Contemporary Educational Technology, 2015, 6(3), 221-238.

7. Blaschke, L. M., Porto, S., \& Kurtz, G. (2010). Assessing the added value of web 2.0 tools for e-learning: The MDE experience. In Proceedings of the European Distance and E-Learning network (EDEN) Research Workshop.

8. Blaschke, L. M. (2014). Using social media to engage and develop the online learner in self-determined learning. Research in Learning Technology, 22.

9. Bere, A. (2013). Using mobile instant messaging to leverage learner participation and transform pedagogy at a South African University of 
Technology. British Journal of Educational Technology, 44(4), 544561.

10. Berger, C. (2001). Wireless: Changing teaching and learning "everywhere, every time", Educase Review, January/February 2001, Pp.58-59.

11. Bhagwat, H. (2016). How can I use WhatsApp for educational purpose? Retrieved 22 April 2018 from https://www.quora.com/Howcan-I-use-WhatsApp-for-educational-Purpose

12. Blaschke, L. M. (2014). Using social media to engage and develop the online learner in self-determined learning. Research in Learning Technology, 22.

13. Bouhnik, D., \& Deshen, M. (2014). WhatsApp goes to school: Mobile instant messaging between teachers and students. Journal of Information Technology Education Research, 13, 217-231. Retrieved from http://www.jite.org/documents/Vol13/JITEv13ResearchP217231Bouhnik0601.pdf

14. Cavus, N. \& Ibrahim, D. (2008). M-Learning: An experiment in using SMS to support learning new English language words. British Journal of Educational Technology, 40(1),78-91.

15. Chan, L. (2005). WebCT revolutionized e-learning. UBC Reports, 51(7). $\quad$ Retrieved 12 July 2018 from http://news.ubc.ca/ubcreports/2005/05jul07/webct.htm

16. Church, K., \& de Oliveira, R. (2013). What's up with WhatsApp? Comparing mobile instant messaging be-haviors with traditional SMS. Proceedings of the 15th International Conference on Humancomputer Interaction with Mobile Devices and Services (pp. 352-361). New York, USA: ACM. doi: 10.1145/2493190.2493225

17. Cifuentes, O. E., \& Lents, N. H. (2011). Increasing student-teacher interactions at an urban commuter campus through instant messaging and online office hours. Electronic Journal of Science Education, 14(1), 1-13. Retrieved from http://ejse.southwestern.edu/article /view/7314

18. Concept of social media. 22 January, 2018 from https://olanrewaju1552hl043.wordpress.com/2017/05/ 16/concept-ofsocial-media/

19. Davies, F. D. (1989). Perceived usefulness, perceived ease of use, and user acceptance of information technology. MIS Quarterly, 13(3), 319340.

20. Dougherty, E. (2012). Why assignments matter. Retrieved 29 January, 2019 from http://www.ascd.org/publications/books/112048/chapters/WhyAssignments-Matter.aspx 
21. Dunn, J. (2011). The 10 best and worst ways social media impacts education. Retrieved July 11, 2017, from http://www.edudemic.com/social-media-education/

22. Dunn, L. (2013). Teaching in higher education: can social media enhance the learning experience?

23. Etim, P. J., Udosen, I. N. and Ema, I. B. (2016) Utilization of WhatsApp and students' Performance in Geography in Uyo Educational Zone, Akwa Ibom State. International Journal of Innovation and Research in Educational Sciences, 3(5), 2349-5219.

24. Gachago, D.; Strydom, S.; Hanekom, P.; Simons, S. \& Walters, S. (2015). Crossing boundaries: lecturers' perspectives on the use of WhatsApp to support teaching and learning in Higher Education. Progression: South African Journal for Open and Distance Learning Practice. Vol 37, No 1 (2015). Retrieved 25 January, 2019 from https://www.researchgate.net/

publication/290339914_Crossing_boundaries_lecturers\%27_perspect ives_on_the_use_of_WhatsApp_to_support_teaching_and_learning_i n_Higher_Education

25. Gillingham, M. G. \& Topper, A. (1999). Technology in teacher preparation: Preparing teachers for the future. Journal of Technology \& Teacher Education, 7(4), 303-321.

26. Griesemer, J. A. (2012). Using social media to enhance students' learning experiences. Quality Approaches in Higher Education Vol. 3 No. 1, p. 8-11.

27. Hendricks, D. (2013). Complete history of social media: Then and now. Retrieved 21 June, 2018 from https://smallbiztrends.com/2013/05/the-complete-history-of-socialmedia- infographic.html

28. Tinti-Kane, H. (2013). Overcoming hurdles to social media in education. Retrieved 21 June 2018 from http://www.educause.edu/ero/article/overcoming-hurdles-socialmedia-education

29. Horrigan, J. B. (n.d.). The meaning of digital readiness. Retrieved 21 June 2018 from http://www.pewInternet.org/2016/09/20/the-meaningof-digital-readiness/

30. Inan, F. A., Flores, R., Grant, M.M. (2010). Perspectives on the design and evaluation of adaptive web based learning environments. Contemporary Educational Technology, 2010, 1(2), 148-159.

31. Jungo, R., Heiberger, G., \& Loken, E. (2011). The effect of twitter on college student engagement and grades. Journal of computer assisted learning, 27(2), 119-132. 
32. Ketineni, A. V. K. (2016). How can I use WhatsApp for educational purpose? Retrieved 22 January 2018 from https://www.quora.com/How-can-I-use-WhatsApp-for-educationalPurpose

33. Kombo, D. K. \& Tromp D. L. A. (2006). Proposal and thesis writing: An introduction. Nairobi: Paulines Publications Africa.

34. Kurniasih, N. \& Riyadhsyah, T. (2018). Virtual ethnography study of inter-lecturer communication in national young lecturers forum WhatsApp group. Retrieved 28 January, 2019 from https://www.researchgate.net/publication/322938774_Virtual_Ethnog raphy Study_of_Interlecturer_Communication_in_National_Young_Lecturers_Forum_ WhatsApp_ Group

35. Laird, T. F. N., \& Kuh, G. D. (2005). Student experiences with information technology and their relationship to other aspects of student engagement. Research in Higher Education, 46(2), 211-233.

36. Leedy, P. D. \& Ormrod, J. E. (2001). Practical research: Planning and design (7th Ed.). Upper Saddle River, New Jersey: Prentice-Hall.

37. Makoe, M. (2010). Exploring the use of MXit: a cell-phone social network to facilitate learning in distance education. Open Learning, 25(3), 251-257.

38. Nassar, D. A, (2016). Using social network as an education enhancement tools: A case study of using WhatsApp in Princess Nourah University. Journal of educational and instructional studies In the world June 2016, Volume: 6 Special Issue 1

39. Negative effect of social media on education. Retrieved 22 August 2018 from http://cassidy education.co.uk/can-social-mediaimprove-learning/

40. Nguyen, D. T., \& Fussell, S. R. (2016). Effects of conversational involvement cues on understanding and emotions in instant messaging conversations. Journal of Language \& Social Psychology, 35(1), 2855. doi: $10.1177 / 0261927 X 15571538$

41. Oriji, A. \& Amadi, R. O. (2016). Emerging technologies in education: Examining the role of online communication in Nigerian education system. Journal of Nigerian Association for Educational Media and Technology (JEMT). Vol. 20, Issue 1, No. 1. Pp. 45-57.

42. Person (2010). In Nassar, D. A, (2016). Using social network as an education enhancement tools: A case study of using WhatsApp in Princess Nourah University. Journal of educational and instructional studies In the world June 2016, Volume: 6 Special Issue 1 Article: 04 ISSN: 2146-7463 
43. Pitler, H., Hubbell, E. R., \& Kuhn, M. (2012). Using technology with classroom instruction that works. Virginia: Association for Supervision and Curriculum Development (ASCD).

44. Plana, M. G- C., Escofet, M. I. G., Figueras, I. T., Gimeno, A., Appel, C., \& Hopkins, J. (2013). Improving learners' reading skills through instant short messages: A sample study using WhatsApp. 4th WorldCALL Conference, Glasgow. Retrieved 14 Jasnuary, from https://www.researchgate.net/publication/255718202_Improving_lear ners'_reading_skills_through_instant_short_messages_a_sample_stud y_using_WhatsApp

45. Prensky, M. (2001). Digital natives, digital immigrants, part 1. On the horizon, 9(5), 1- 6.

46. Rambe, P. \& Chipunza, C. 2013. Using mobile devices to leverage student access to collaboratively-generated resources: A case of WhatsApp instant messaging at a South African university. International Conference on Advanced Information and Communication Technology for Education. South Africa: Atlantis Press.

47. Seaman, J., \& Tinti-Kane, H. (2013). Social media for teaching and learning. UK: Pearson Learning Systems.

48. Shanmugapriya, S. \& Veerakumar, K. (2016). A comparative study on SMS vs. WhatsApp users. International Journal of Current Research and Modern Education (IJCRME). Volume I, Issue II, 2016. (Online) P. $2455-5428$

49. Sharpe, B. (2006). The ambient web. In Stead, G.; Sharpe, B.; Anderson, P.; Cych, L. \& Philpott, M. (2006). Emerging technologies for learning. Retrieved 30 January, 2019 from https://hdera.ioe.ac.uk/1501/1/becta_2006 emergingtechnologies_vol1_report.pdf

50. Singhal, V. (2016). How can I use Whats App for educational purpose? Retrieved 12 January, 2018 from https://www.quora.com/How-canI-use-WhatsApp-for-educational-Purpos

51. Smit, I. (2012). WhatsApp with BlackBerry; Can messengers (BBM) be MXit? In Proceedings of the 14th annual conference on World Wide Web applications. Cape Town, South Africa: Cape Peninsula University of Technology. Retrieved 17 December, from http://hdl.handle. Net/10394/1362

52. Smith, R. (2015). The role of social media in higher education marketing. Retrieved May 12, 2018 from http://www.bostoninteractive.com/blog/industries/social-mediahigher- education -marketing 
53. Snelbecker, G. E. (1999). Some thoughts about theories, perfection and instruction. New Jersey: Lawrence Erlbaum+

54. Stead, G. (2006). Mobile technologies: transforming the future of learning. In Stead, G.;Sharpe, B et al (2006). Emerging technologies for learning. Retrieved 30 January, 2019 from https://dera.ioe.ac.uk/1501/1/becta_2006 emergingtechnologies_vol1_report.pd

55. Ta'amneh, M. A. A. A. (2017). The effect of using WhatsApp messenger in learning English language among university students. International Research in Education. 2017, Vol. 5, No. 1

56. Tarus, J. K, Gichoya, D. \& Muumbo, A. (2015). Challenges of implementing e-learning in Kenya: a case of Kenyan public universities. $\quad$ http://www.irrodl.org/index.php/irrodl/article /view/1816/3196

57. Tinti-Kane, H. (2013). Overcoming hurdles to social media in education. $\quad$ Retrieved $10 \quad$ April 2018 from http://er.educause.edu/articles/2013/4/overcoming-hurdles-to-socialmedia-in-education

58. Ubell, R. (2017). Online cheating. Retrieved 11 February, 2017 from https://www.inside highered.com/digitallearning/views/2017/02/06/robert-ubell-online-cheating-and-whatcolleges-can-do-about-it

59. Vygotsky, L.S. (1978). Mind in society: The development of higher psychological processes. Cambridge. MA: Havard University Press.

60. What are the advantages and disadvantages of WhatsApp? Retrieved 11 September 2018 from https://www.quora.com/What-are-theadvantages-and-disadvantages-of-WhatsApp

61. WhatsApp for Education. Retrieved 11 November 2017 from http://www.wapp4phone.com/ facts/WhatsApp-education/

62. Wheeler, S. (2010). ICT and the changing role of the teacher. Retrieved 9 February, 2019 from file://C:/Users/ICTC/Desktop/ALL\%20DIRECTORIES/CONFERE NCES/10-9-2018\% 20TEACHERS\%20CHANGING\%20ROLE/ICT\%20and\%20the\%20 changing\%20role\%20of\%20the\%20teacher.htm

63. Yin, L. C. (2016). Adoption of WhatsApp instant messaging among students in Ipoh higher education institutions lee chin yin

64. Zengin, B., Arikan, A., Dogan, D. (2011). Opinions of English Major Students about Their Departments' Websites. Contemporary Educational Technology, 2(4), 294-307. 
65. Zhao, T. \& Cziko, G. 2001. Teachers' Adoption of Technology: A Perceptual Control Theory Perspective. Journal of Technology and Teacher Education, 9(1), 15-30. 